\title{
Air quality in Barcelona during the COVID-19 lockdown and the global effect on $\mathrm{CO}_{2}$ emissions
}

\author{
Calidad del aire en Barcelona durante el confinamiento \\ por la COVID-19 y su efecto global en las emisiones de $\mathrm{CO}_{2}$
}

Javier Martín-Vide

jmartinvide@ub.edu

Alberto Zayas

albertozayas@gmail.com

Ferran Salvador

fsalvador@ub.edu

Ma Carmen Moreno-García

mcmoreno@ub.edu

Departament of Geography

Universitat de Barcelona (Spain)

\begin{abstract}
The COVID-19 pandemic is having an enormous negative impact on human health, with more than 4.44 million deaths worldwide; on the economy, with an unprecedented deep and abrupt crisis; and on society, with millions of people facing unemployment and dependent, in the bestcase scenario, on public welfare or social aid systems. Home confinement, measures to limit nonessential economic activity and travel restrictions in many countries during the spring of 2020 led
\end{abstract}


to rapid air quality improvements in cities. A detailed analysis of Barcelona's daily immissions of seven pollutants $\left(\mathrm{CO}, \mathrm{SO}_{2}, \mathrm{NO}, \mathrm{NO}_{2}, \mathrm{NO}_{x}, \mathrm{PM}_{10}\right.$ and $\left.\mathrm{O}_{3}\right)$ shows a clear decrease from midMarch to June, with the peak in April and the nitrogen oxides. For these pollutants the reduction of traffic density is very likely the main cause of their immissions decrease. On another note, the global reduction of $\mathrm{CO}_{2}$ emissions derived from the use of fossil fuels was estimated at approximately $8 \%$ in 2020, which, despite constituting an unprecedented drop, will have little impact on concentrations of $\mathrm{CO}_{2}$ and other greenhouse gases in the atmosphere. The current situation must be seen as an opportunity to push, without delay, for a drastic change in the energy and economy models towards a socio-environmental paradigm based on sustainability, economic efficiency and solidarity between peoples.

Key words: climate change; pollutant immissions; greenhouse gasses; nitrogen oxides.

\section{Resumen}

La pandemia de la COVID-19 está teniendo un enorme impacto negativo en la salud humana, con más de 4,44 millones de muertos en todo el mundo; en la economía, con una profunda y abrupta crisis sin precedentes; y en la sociedad, con millones de personas en situación de desempleo y dependientes, en el mejor de los casos, de los sistemas de asistencia social o de bienestar público. El confinamiento domiciliario, las medidas para limitar la actividad económica no esencial y las restricciones de los viajes en muchos países durante la primavera de 2020 llevaron a mejoras rápidas en la calidad del aire de las ciudades. Un análisis detallado de las inmisiones diarias de Barcelona de siete contaminantes $\left(\mathrm{CO}, \mathrm{SO}_{2}, \mathrm{NO}, \mathrm{NO}_{2}, \mathrm{NO}_{\mathrm{x}}, \mathrm{PM}_{10}\right.$ y $\mathrm{O}_{3}$ ) muestra una clara disminución desde mediados de marzo hasta junio, con el pico en abril y en los óxidos de nitrógeno. Para estos contaminantes, la reducción de la densidad del tráfico es muy probablemente la principal causa de la disminución de sus inmisiones. Por otro lado, la reducción global de las emisiones de $\mathrm{CO}_{2}$ derivadas del uso de combustibles fósiles se estimó en aproximadamente un $8 \%$ en 2020, lo que, a pesar de constituir una caída sin precedentes, tendrá poco impacto en las concentraciones de $\mathrm{CO}_{2}$ y de otros gases de efecto invernadero en la atmósfera. La situación actual debe ser vista como una oportunidad para impulsar, sin demora, un cambio drástico en los modelos energético y económico hacia un paradigma socioambiental basado en la sostenibilidad, la eficiencia económica y la solidaridad entre los pueblos.

Palabras clave: cambio climático; inmisiones contaminantes; gases de efecto invernadero; óxidos de nitrógeno. 


\section{Introduction. Research questions}

The COVID-19 pandemic has highlighted the complexity of the world in which we live. It is a complexity that goes beyond the number of humans on the planet (currently more than 7.5 billion), although, pending a debate on Earth's carrying capacity, population size almost certainly complicates the issue. Today's world is undeniably changing and uncertain (Martín Vide, 2012). Changing, because it is hurtling at an accelerated pace through a succession of political, economic, social and environmental events and upheavals that come so fast we are left with no time to steer them in the right direction or reflect on them calmly. Uncertain, because the changes are unpredictable and surprising, especially when our analysis is superficial or partial. Only disciplines capable of taking comprehensive, cross-cutting approaches, such as Geography, can fully address the complexity of today's world and glimpse the changes to come.

Today, this complexity can manifest itself on any scale, be it global or local. From our home, a planet of only $40,000 \mathrm{~km}$ in circumference affected by inequity, injustice, the unsustainable consumption of its resources and the generation of an enormous volume of waste; to our towns and cities with their daily issues around coexistence, the management of public services, segregation, public health, etc. All are problems known to geographical science, which is in a unique position to undertake a comprehensive analysis of both global problems, and those that affect us on a more local level to advance the search for solutions.

There is a general consensus (conspiracy and denialist theories notwithstanding), that, of all the problems facing the world today, climate change is one of the most substantive and challenging to solve, although, paradoxically, its diagnosis and remedy are known. By 2009, thirty-one authors, including a Nobel laureate, had already pointed to this fact in the reference article "Planetary boundaries: exploring the safe operating space for humanity in Ecology and Society" (Rockström et al., 2009), when they put climate change at the top of the list of environmental problems with associated limits for the planet; limits that, if exceeded, would have severe or irreversible repercussions.

It should be noted that the climate change we are witnessing today is more than a mere environmental problem. It is a problem caused by the prevailing capitalist economic model, particularly the fossil-fuel-based energy model, but it is also a social problem related to equity, social justice, and even health, as was published in The Lancet in 2009 (Costello et al., 2009).

Some say, with good judgement, that the great post-COVID-19 pandemic will be climate change. That while it is now half silent, muffled by the tragedy of those affected and lost to SARS-CoV-2, 
obliterated by the fear of contagion, by the images of medical personnel tested to their very limits and by so many other images we could never have imagined just a year ago, it will re-emerge in all its gravity. And even though humanity has far from defeated the current pandemic, two questions need our urgent attention: given the stoppages and closure of many activities and companies, especially during the lockdowns, has COVID-19 impacted global warming by reducing greenhouse gas emissions? In a marked counterpoint to the metaphorical darkness of the moment, has the air quality in our cities really improved, as the images of smog-free skies and good visibility during the strictest confinements would seem to suggest?

\section{Objectives and methodological procedures}

The primary objective of this article is to advance our understanding of the impact of the COVID-19 pandemic on global warming and air quality in cities. Broken down, the specific objectives are: 1) reflect on the "double" pandemic, COVID-19 and climate change, from a geographical perspective; and 2) evaluate the impact of the first state of alert (March-June 2020) on urban air quality in the city of Barcelona. Additionally, in light of available assessments, the likely impact of the COVID-19 lockdown on global $\mathrm{CO}_{2}$ emissions and other greenhouse gases in 2020 is debated.

The methodological procedures used were as follows: 1) a review and comparison of prospective studies on global $\mathrm{CO}_{2}$ emissions in 2020 and 2) a statistical and temporal analysis of the values of various air pollutants in the city of Barcelona during the first six months of 2020. For the latter, the analysis was based on hourly measurements of seven air pollutants taken from four environmental control stations in the city and complemented by monthly meteorological analyses for the first half of 2019 and 2020.

\section{Air quality in Barcelona during the COVID-19 lockdown in the first half of 2020}

\subsection{Data and procedures}

Two types of data were used: air pollution measurements and meteorological reports. The former came from the stations that form part of the Government of Catalonia's Air Pollution Monitoring and Forecasting Network (Xarxa de Vigilància i Previsió de la Contaminació Atmosfèrica - XVPCA) which analyses the broadest range of pollutants in the city of Barcelona: Eixample, Gràcia-Sant Gervasi, Parc Vall d'Hebron and Palau Reial. The meteorological data was provided by Spain's State Meteorological Agency (AEMET) and the Catalan Meteorological Service (METEOCAT). 
For the XVPCA network, the data on immissions (concentrations in a specific place and time) were downloaded from Barcelona City Council's Open Data BCN website and the Open Data website managed by the Government of Catalonia. The data was obtained in CSV format and processed with Excel.

Using the hourly data for each pollutant and station, we calculated the daily average, thus converting, in each case, the 24 hourly values per day to one daily averaged value. This action was repeated for every day between 1 January and 21 June, for both 2019 and 2020. The only operational difference between the two years is that as 2020 was a leap year, it has one additional value on 29 February. We calculated 341 operations or daily average values for each pollutant and monitoring station, which, in total, gave us almost 10,000 daily values for the seven pollutants and four measuring stations.

To account for the influence of environmental factors on the air pollution measurements, we also considered the meteorological conditions at the time of the immissions. To do this, we used AEMET's "monthly climatological summaries" for Catalonia during the months of the study, as well as METEOCAT'S "monthly bulletins" and climate mapping for rainfall accumulation.

Additionally, data from two traffic counting points in the vicinity of the Eixample pollutant measurement station have been taken into account. The source of these data is the City Council opendata. ${ }^{1}$

\subsection{Details of the XVPCA stations used}

Barcelona has eight surface pollutant measuring stations heterogeneously distributed around the city, from the Poblenou station, at $3 \mathrm{~m}$ above sea level, to the Fabra Observatory, at $415 \mathrm{~m}$ above sea level. There are two types of station: urban traffic stations and urban background stations. The former measure the levels of immissions related to road traffic, and the latter, the levels of pollutants in the city once mixed and not affected by nearby emissions sources. Depending on their location, the stations are classified as urban, suburban or rural. Barcelona has seven urban stations and one sub-urban station at the Fabra Observatory in the Collserola coastal range.

For the purposes of this study, we used the measurements recorded by the four stations that analyse the highest number of pollutants (Figure 1): 
- The Eixample urban traffic station, located at Avinguda de Roma junction with Carrer Comte d'Urgell, UTM coordinates (m) 41.385315, 2.1537998, altitude 26 m above sea level. In operation since the first day of 1984. It measures $\mathrm{NO}_{2}, \mathrm{CO}, \mathrm{O}_{3}, \mathrm{SO}_{2}, \mathrm{PM}_{10}, \mathrm{NO}$ and $\mathrm{NO} x$ immissions.

- The Gràcia-Sant Gervasi urban traffic station, located in the Plaça de Gal.la Placídia, UTM coordinates $(\mathrm{m})$ 41.398724, 2.1533988, altitude $57 \mathrm{~m}$ above sea level. In operation since November 1997. It measures $\mathrm{NO}_{2}, \mathrm{CO}, \mathrm{O}_{3}, \mathrm{SO}_{2}, \mathrm{PM}_{10}, \mathrm{NO}$ and $\mathrm{NO}$ immissions.

- The Parc Vall d'Hebron urban traffic station is located on Avinguda de Martí de Codolar, UTM coordinates $(\mathrm{m})$ 41.42611, 2.1480017, altitude $136 \mathrm{~m}$ above sea level. In operation since 4 November 1997. It measures $\mathrm{NO}_{2}, \mathrm{CO}, \mathrm{O}_{3}, \mathrm{SO}_{2}, \mathrm{PM}_{10}, \mathrm{NO}$ and $\mathrm{NO}$ immissions.

- The Palau Reial urban background station is located at Carrer de Jordi Girona junction with Carrer Tinent Coronel Valenzuela, UTM coordinates (m) 41.38749, 2.1151996, altitude $81 \mathrm{~m}$ above sea level. In operation since the first day of 2011. It measures $\mathrm{NO}_{2}, \mathrm{CO}, \mathrm{O}_{3}, \mathrm{SO}_{2}$, $\mathrm{PM}_{10}, \mathrm{NO}$ and $\mathrm{NO}$ immissions.

Figure 1. Partial orthophoto of Barcelona showing the location of the four XVCPA stations used in the study

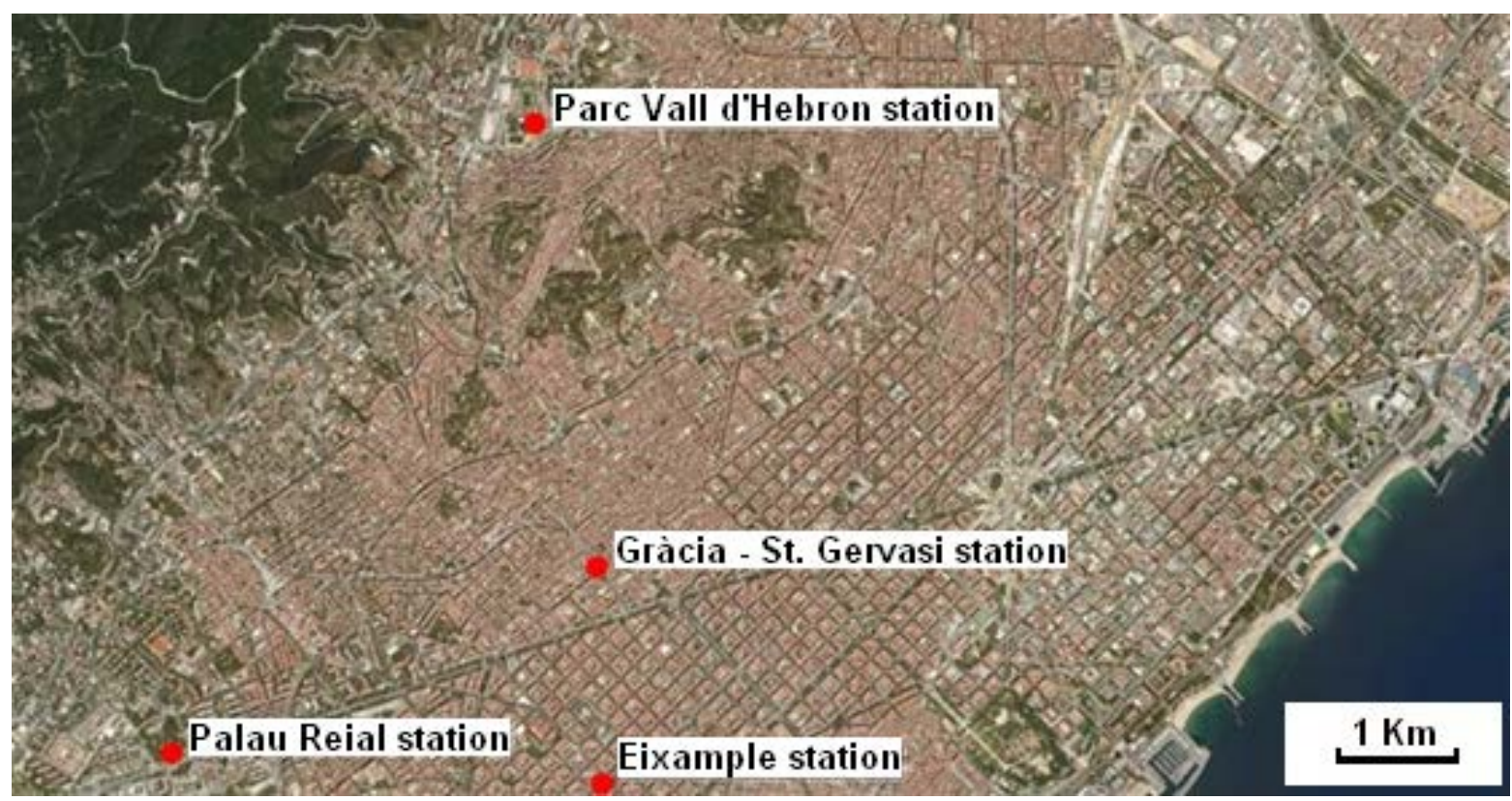

Source: authors' own elaboration based on an orthophoto OF-25C 2019 from the Cartographic and Geological Institute of Catalonia (ICGC) 


\subsection{Meteorological influences on pollutant immissions in the first half of 2020 compared to 2019}

To properly assess the pollutant immissions, we analysed Barcelona's meteorological conditions during the first state of alert due to COVID-19 and compared them to data for the same period in 2019. Specifically, we considered the data on rainfall, atmospheric pressure and wind speed. It is entirely plausible to expect that the drastic reduction in mobility and the stoppage of industrial activity during the state of alert would have influenced the level of polluting emissions. However, we must also remember that atmospheric conditions directly impact immissions, to the extent that they can either increase their concentration or favour their dispersion.

To build up a picture of the conditions during the period of study (the first state of alert) and the corresponding period in 2019, we referred to the 2019 and 2020 "monthly climatological summaries" for March, April, May and June. The summaries were sourced from the Territorial Delegation of the State Meteorological Agency (AEMET) in Catalonia, and the Catalan Meteorological Service (METEOCAT).

March 2019 was warm and dry with light winds. High-pressure dominated on most days. Of the four rainfall episodes that occurred in Catalonia during the month, none affected the city of Barcelona. The total rainfall recorded in Barcelona was minimal, between $0.1 \mathrm{~mm}$ and $0.7 \mathrm{~mm}$. March 2020 was also warm, but, unlike March 2019, it was humid and windy. Days 2, 17 and 31 stand out with average wind speeds of 30,45 and $34 \mathrm{~km} / \mathrm{h}$, respectively. Furthermore, three episodes of rainfall affected the Barcelonès region's coastal areas, the most significant of which occurred on 23 March, when about $20 \mathrm{~mm}$ was recorded in Barcelona. Total rainfall for the month was $60 \mathrm{~mm}$.

April 2019 in Catalonia was typical in terms of temperatures and rainfall. However, the precipitation was unevenly distributed, and very little fell in the city of Barcelona. Even so, the Catalan capital saw rain on several days; daily values were between 3 and $7 \mathrm{~mm}$ with accumulation of around $20 \mathrm{~mm}$, except at the Fabra Observatory, which recorded double that amount. With regard to wind, between days 18 and 21 and coinciding with a decrease in atmospheric pressure, the stations recorded average daily wind speeds above $40 \mathrm{~km} / \mathrm{h}$. April 2020, on the other hand, was the wettest April on record in the region after 1942, 1969 and 1946. Barcelona airport and the Fabra Observatory recorded maximums that exceeded all their historical series measurements, with monthly totals surpassing 263 and $250 \mathrm{~mm}$, respectively. On 13 April 2020, there were widespread showers on the coast with values above $50 \mathrm{~mm}$. Between 
days 18 and 21 of the same month, many towns near Barcelona also broke the maximum daily records in their historical series. The city of Barcelona recorded considerable daily rainfall measurements of between 75 and $80 \mathrm{~mm}$. The episode of low pressure produced daily average wind speeds of approximately $30 \mathrm{~km} / \mathrm{h}$.

May 2019 was humid, with three notable rainfall episodes in Barcelona accumulating monthly totals of between 70 and $110 \mathrm{~mm}$. The first of the three episodes took place at the beginning of the month, with daily rainfall in excess of $20 \mathrm{~mm}$. The second took place in the third week. It lasted three days and coincided with the minimum monthly atmospheric pressure values. Between these two episodes and linked to the decrease in atmospheric pressure, the windiest days were recorded, with average speeds of close to $30 \mathrm{~km} / \mathrm{h}$. The last of the three rainfall episodes occurred at the end of the month. It was similar to the second but shorter in duration. By contrast, May 2020 was a particularly warm month. In fact, AEMET confirmed it as the warmest May since 1940 and METEOCAT said it surpassed May 2015, the warmest May on record for decades. The rainfall in this month was unevenly distributed across Catalonia. In Barcelona, the heaviest rainfall occurred between days 10 and 16 when a persistent low pressure contributed $20 \mathrm{~mm}$ of precipitation and average daily wind speed records of approximately $20 \mathrm{~km} / \mathrm{h}$.

June 2019 was hot and dry throughout the region. Rain was only recorded in the city on one day (day 11), with measurements between 18 and $25 \mathrm{~mm}$. Wind strength was moderate, registering average daily speeds of between 10 and $18 \mathrm{~km} / \mathrm{h}$. June 2020, on the other hand, was, in general, a cool month in Catalonia. According to AEMET, it was the third coldest in 20 years after June 2013 and 2010. However, the low thermal values were tempered in the city of Barcelona and in some coastal areas. As for rainfall, Barcelona accumulated $44 \mathrm{~mm}$ over nine days. The wind speed values were similar to those of the previous month and during the same period of 2019. The daily average values recorded on the June days affected by the state of alert were between 10 and $20 \mathrm{~km} / \mathrm{h}$.

\subsection{Results}

a) Analysis of carbon monoxide (CO) immissions, January-June 2019 and 2020

In both 2019 and 2020, and at all four air pollution control stations, the carbon monoxide (CO) immissions recorded in January and February were higher than those recorded from March to June. The first two months of the year also saw the most extensive range of values. Both these wide ranges and the highest values were recorded at the Eixample and Gràcia-Sant Gervasi stations (Figure 2), with maximums close to $1.5 \mathrm{mg} / \mathrm{m}^{3}$. By contrast, the immissions recorded at 
Parc Vall d'Hebron and Palau Reial had lower values, particularly at the latter. From March onwards, the immissions recorded by the four stations decreased for both the 2019 and 2020 series. Barring an occasional exception, the measurements recorded in 2020 were lower than those recorded in 2019. The most significant reduction in immissions between 2019 and 2020 was seen at the Eixample station during the initial period of the first state of alert (55.7\%) and the stoppage of non-essential activities (45.8\%). Conversely, the carbon monoxide immissions recorded at Parc Vall d'Hebron between 30 March and 9 April 2020 saw an increase of $17.0 \%$ compared to the same period in 2019.

Figure 2. Daily evolution of carbon monoxide (CO) immissions at the Gràcia-Sant Gervasi station

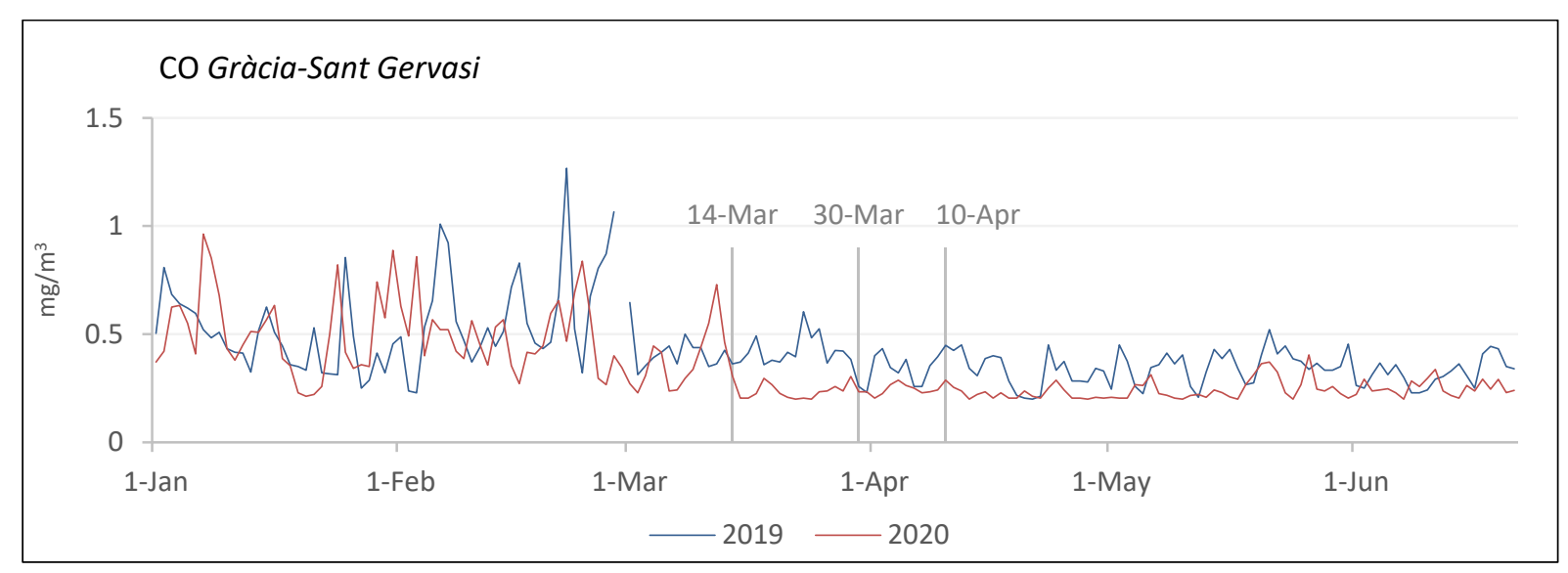

Source: authors' own elaboration based on data from the XVPCA

b) Analysis of sulphur dioxide ( $\left.\mathrm{SO}_{2}\right)$ immissions, January-June 2019 and 2020

The sulphur dioxide $\left(\mathrm{SO}_{2}\right)$ immissions show two different patterns in Barcelona. At the Eixample (Figure 3) and Gràcia-Sant Gervasi stations, the ranges are broader, and the values higher. The latter recorded a maximum daily peak of $5 \mu \mathrm{g} / \mathrm{m}^{3}$ in both 2019 and 2020, which is a highly unusual value. The values recorded at Vall $d^{\prime}$ Hebron and Palau Reial were more contained for all the months studied. However, those recorded in 2020 during the first state of alert were generally lower than those recorded in the same period of the previous year, which was not the case before the state of alert was declared.

At the Eixample station, the most significant reduction in values between 2019 and 2020 was seen during the stoppage of non-essential activities (28.6\%). By contrast, the Vall $d^{\prime} H e b r o n$ and Palau Reial stations saw the most significant reduction in comparative immissions during the initial days of the state of alert between 14 March and 29 March, when they reduced by $27.32 \%$ and 
$14.7 \%$, respectively. Interestingly and somewhat unusually, compared to the equivalent period in 2019, the Gràcia-Sant Gervasi station recorded a 74.6 \% increase in $\mathrm{SO}_{2}$ immissions after the state of alert was decreed. Moreover, on the days affected by the stoppage of non-essential activities, immissions doubled, increasing by $108.3 \%$. From that period to the end of the state of alert, they rose by 53.5 \% compared to the same period in 2019 . Therefore, we can assume that these results depict an anomaly in relation to the behaviour of sulphur dioxide immissions.

In the months prior to the pandemic, all the stations, except Vall d'Hebron, recorded lower immissions than in the corresponding months in 2019.

Figure 3. Daily evolution of sulphur dioxide $\left(\mathrm{SO}_{2}\right)$ immissions at the Eixample station

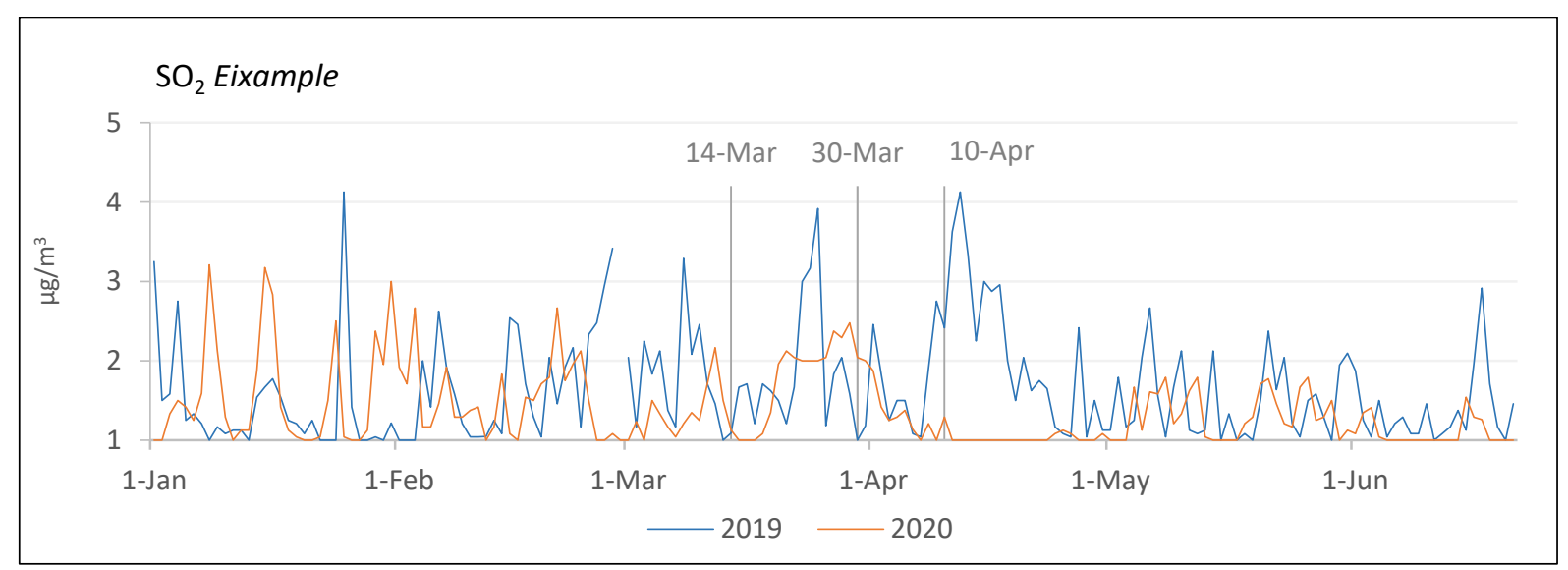

Source: authors' own elaboration based on data from the XVPCA

c) Analysis of nitrogen oxide (NO) immissions, January-June 2019 and 2020

The nitrogen oxide or nitric oxide (NO) immissions recorded at the Eixample (Figure 4) and Gràcia-Sant Gervasi stations were similar. However, they differed from those recorded at the other two. The data series at these stations show maximums in excess of $100 \mu \mathrm{g} / \mathrm{m}^{3}$, with peaks of up to $120 \mathrm{\mu g} / \mathrm{m}^{3}$, three times the annual legislated threshold. From March onwards, but before the first state of alert, the immissions were more uniform, with a smaller range and within the maximum legislated threshold, especially in the 2020 series. Conversely, the other two stations, Vall d'Hebron and Palau Reial, recorded less dispersed values with a smaller range, especially from March when the measurements decreased to minimum values. In all months, the values for 2019 were slightly higher than those of 2020 .

During the first state of alert, all four measuring points recorded reduced NO immissions compared to the same period of the previous year. Of particular note were the 70-80\% reductions recorded between day 14 and 29 in March, at Eixample, Gràcia-Sant Gervasi and 
Palau Reial. During the stoppage of all non-essential activity, the reductions fluctuated between 55.2 and $70.8 \%$. Subsequently, until the end of the first state of alert the immissions in 2020 show reductions of $35.7 \%$ at the Vall $d^{\prime}$ Hebron station and $60.8 \%$ at the Eixample station.

Figure 4. Daily evolution of nitrogen oxide immissions (NO) at the Eixample station (dashed line: maximum legislated limit)

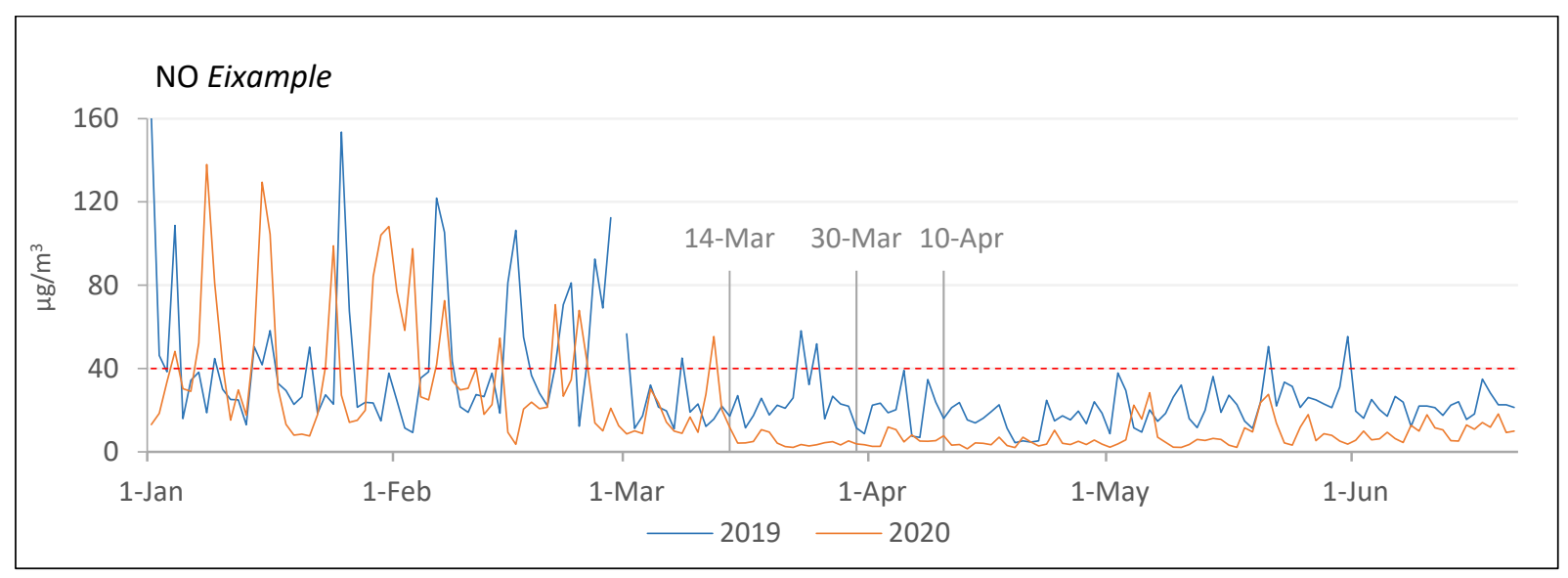

Source: authors' own elaboration based on data from the XVPCA

d) Analysis of nitrogen dioxide $\left(\mathrm{NO}_{2}\right)$ immissions, January-June 2019 and 2020

With regards to nitrogen dioxide $\left(\mathrm{NO}_{2}\right)$, the four stations again presented two different patterns. The first pattern can be observed in the Eixample (Figure 5) and Gràcia-Sant Gervasi stations, which have remarkably similar graphs: wide-ranging values, especially from January to March, peaks above $90 \mu \mathrm{g} / \mathrm{m}^{3}$ and values above the legislated threshold until the beginning of the first state of alert. From this moment on, $\mathrm{NO}_{2}$ declines slightly in 2019 and categorically in 2020. A similar pattern can be seen at Vall d'Hebron and Palau Reial, but with more contained values, especially in the 2020 series.

When comparing 2020 to the previous year, we can see a consistent pattern of reduced immissions, on a percentage basis. The most notable variations in 2020 occurred during the three periods of the first state of alert: the initial lockdown, the stoppage of all non-essential activity, and the final stage of the measures. The most pronounced decreases were seen during the initial lockdown, with a more than $60 \%$ reduction compared to 2019 at the Eixample and Gràcia-Sant Gervasi stations. 
Figure 5. Evolution of nitrogen dioxide immissions $\left(\mathrm{NO}_{2}\right)$ at the Eixample station (dashed line: maximum legislated limit)

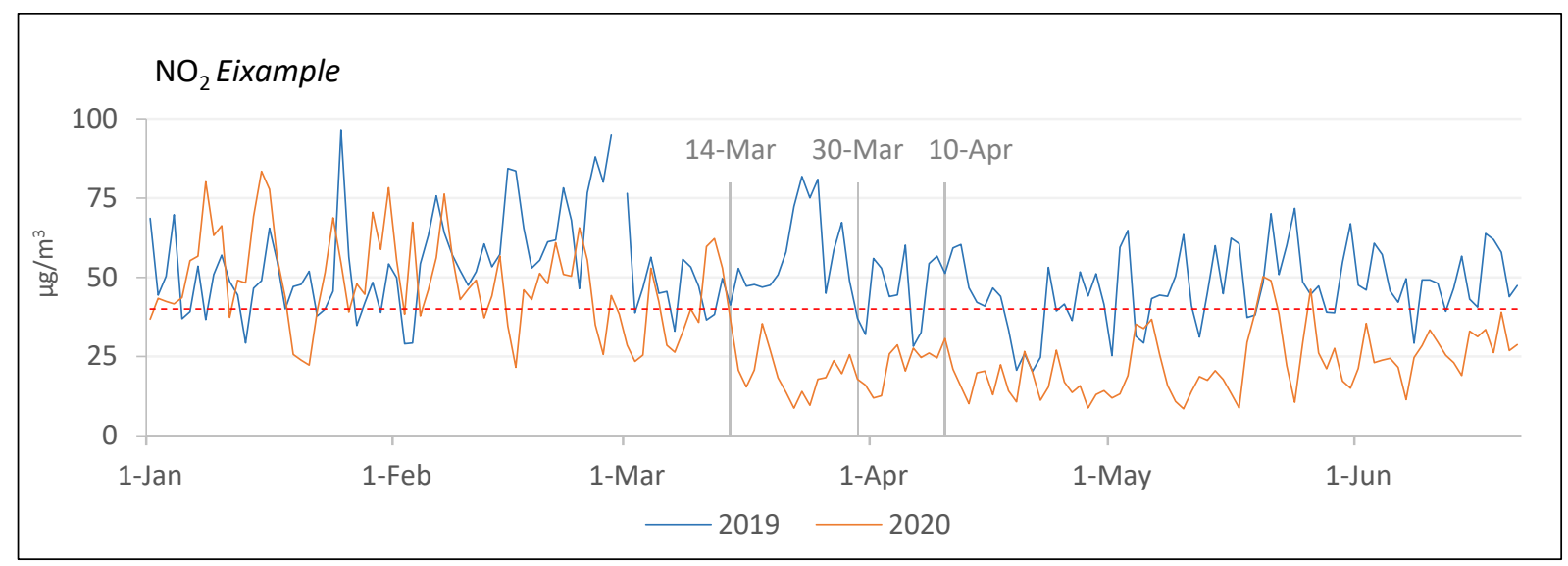

Source: authors' own elaboration based on data from the XVPCA

e) Analysis of nitrogen oxides (NOx) immissions, January-june 2019 and 2020

The Eixample (Figure 6) and Gracia-Sant Gervasi sampling stations saw strong oscillations in nitrogen oxides $\left(N O_{x}\right)$ immissions at the beginning of the year, with almost cyclical maximum peaks above $250 \mathrm{\mu g} / \mathrm{m}^{3}$. From March onwards the charts reflect a downward trend which is more pronounced in 2020 when readings hovered around the maximum legislated limit at approximately $40 \mu \mathrm{g} / \mathrm{m}^{3}$. In contrast, the 2019 graph does not descend as sharply and maintains, despite some oscillations, figures between 50 and $150 \mathrm{ug} / \mathrm{m}^{3}$ at Eixample, and between 40 and $120 \mu \mathrm{g} / \mathrm{m}^{3}$ at Gràcia-Sant Gervasi. The other two stations (Vall d'Hebron and Palau Reial) share similar immissions patterns between them. They have higher and more dispersed values from January to March and then fall below the legislated $40 \mu \mathrm{g} / \mathrm{m}^{3}$ limit, more notably so for the 2020 series.

The most pronounced variations in immissions between 2019 and 2020 occur during the initial period of the first state of alert. Between 14 and 29 March, Eixample, Gràcia-Sant Gervasi and Palau Reial saw reductions of between 67.0 and $71.2 \%$. Vall d'Hebron, on the other hand, saw its most significant reduction during the stoppage of non-essential activities from the 30 March to 9 April, when the recorded immissions were $61.7 \%$ less than during the same period in 2019. In general terms, from the beginning of 2020, $\mathrm{NO}_{x}$ immissions followed a trend of reduced values. The first state of alert pulled the immissions values to within the maximum legislated threshold, and, at Vall d'Hebron and Palau Reial, those values remained below the threshold until the end of the state of alert. 
Figure 6. Evolution of nitrogen oxides immissions $(\mathrm{NO})$

at the Eixample station (dashed line: maximum legislated limit)

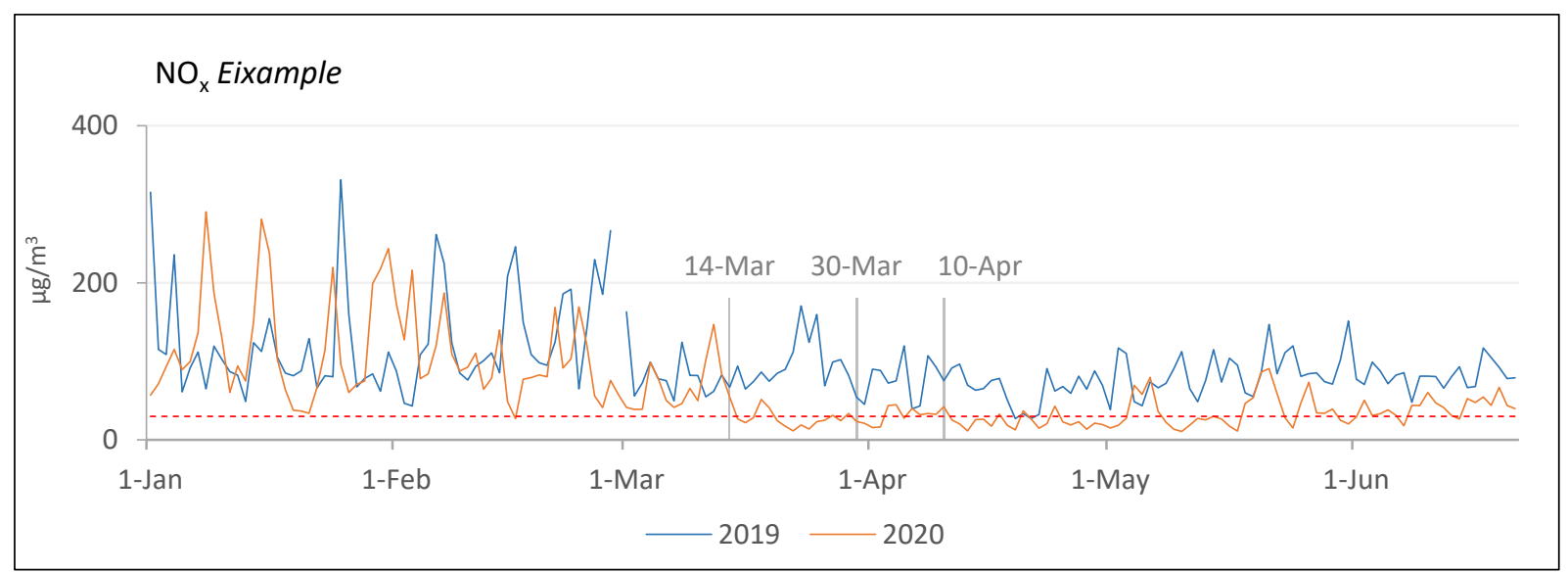

Source: authors' own elaboration based on data from the XVPCA

f) Analysis of suspended particulate matter immissions (PM10), January-June 2019 and 2020

The analysis of particulate matter immissions ( $\mathrm{PM}_{10}$ ) shows a similar pattern at the Eixample, Gràcia-Sant Gervasi and Vall d'Hebron stations (Figure 7). The 2019 figures are almost always below the legislated threshold of $50 \mu \mathrm{g} / \mathrm{m}^{3}$, with all three presenting minimums close to 7 $\mu \mathrm{g} / \mathrm{m}^{3}$ in January. The 2020 series for these three stations also stay mostly below the legislated limit value except for two peaks that reach around $100 \mu \mathrm{g} / \mathrm{m}^{3}$. For its part, the Palau Reial station presents values similar to those of the others but with smaller ranges and less pronounced maximum peaks not exceeding $50 \mu \mathrm{g} / \mathrm{m}^{3}$ in 2019 and climbing just above $60 \mu \mathrm{g} / \mathrm{m}^{3}$ in 2020 .

The first state of alert saw decreases in the daily averages at all stations and in all periods, compared to 2019. The most significant decrease was seen at the Vall d'Hebron station, with reductions of $39.3 \%$ in the initial phase, through to $59.8 \%$ in the subsequent period that included the stoppage of all non-essential activity. The other three stations recorded decreases in PM 10 immissions of between $18.3 \%$ and $38.0 \%$. 
Figure 7. Evolution of suspended particulate matter immissions ( $\left.P M_{10}\right)$ at the Vall d'Hebron station (dashed line: maximum legislated limit)

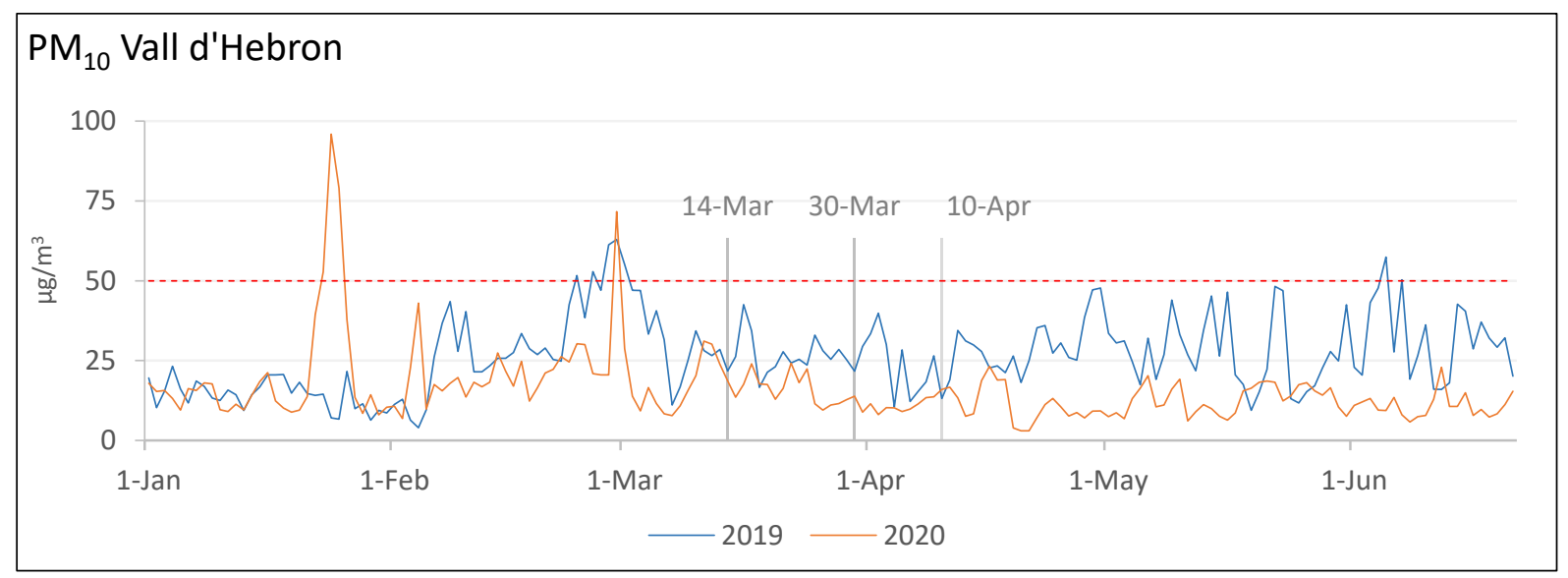

Source: authors' own elaboration based on data from the XVPCA

g) Analysis of ozone $\left(\mathrm{O}_{3}\right)$ immissions, January-June 2019 and 2020

The ozone $\left(\mathrm{O}_{3}\right)$ immissions at all four stations studied were fairly similar in 2019 and 2020. They show minimums at the beginning of the year and then increase progressively until April when the 2019 series shows a daily peak of close to $120 \mu \mathrm{g} / \mathrm{m}^{3}$ (maximum legislated threshold). In the 2020 series, the highest peak occurred at the Palau Reial station in May (Figure 8). For almost the entire period studied, the immissions measurements for 2020 are slightly higher than those in 2019. The highest concentrations occurred throughout the entire period of the first state of alert, with values of up to $100 \mu \mathrm{g} / \mathrm{m}^{3}$. The Palau Reial and Gràcia-Sant Gervasi stations experienced increases of between 2.2 and $40.8 \%$ in all periods under the first state of alarm, compared to the same dates in 2019. The Vall d'Hebron station was the only one to see reduced immissions at all times, albeit very moderate reductions of between 3.1 and $4.0 \%$.

h) Analysis of the influence of traffic on immissions

Regarding the density of traffic and its influence on immissions, in March the average reductions in the two traffic density points were between $59 \%$ on Saturdays and $44 \%$ on weekdays days. In April between $87 \%$ on Sundays and $79 \%$ on Mondays and weekdays days. In May between $77 \%$ on Sundays and $57 \%$ on Fridays. And finally, in June a bit more than $30 \%$ in all the days.

The aforementioned reductions are relatively well related to nitrogen oxides $\left(\mathrm{NO}, \mathrm{NO}_{2}\right.$ and $\mathrm{NO}_{\mathrm{x}}$ ) reductions, although the former are larger. In the other pollutants the relationship is not so clear.

i) Overview of immissions and interpretation of results 
Figure 8. Evolution of ozone $\left(\mathrm{O}_{3}\right)$ immissions

at the Palau Reial station (dashed line: maximum legislated limit)

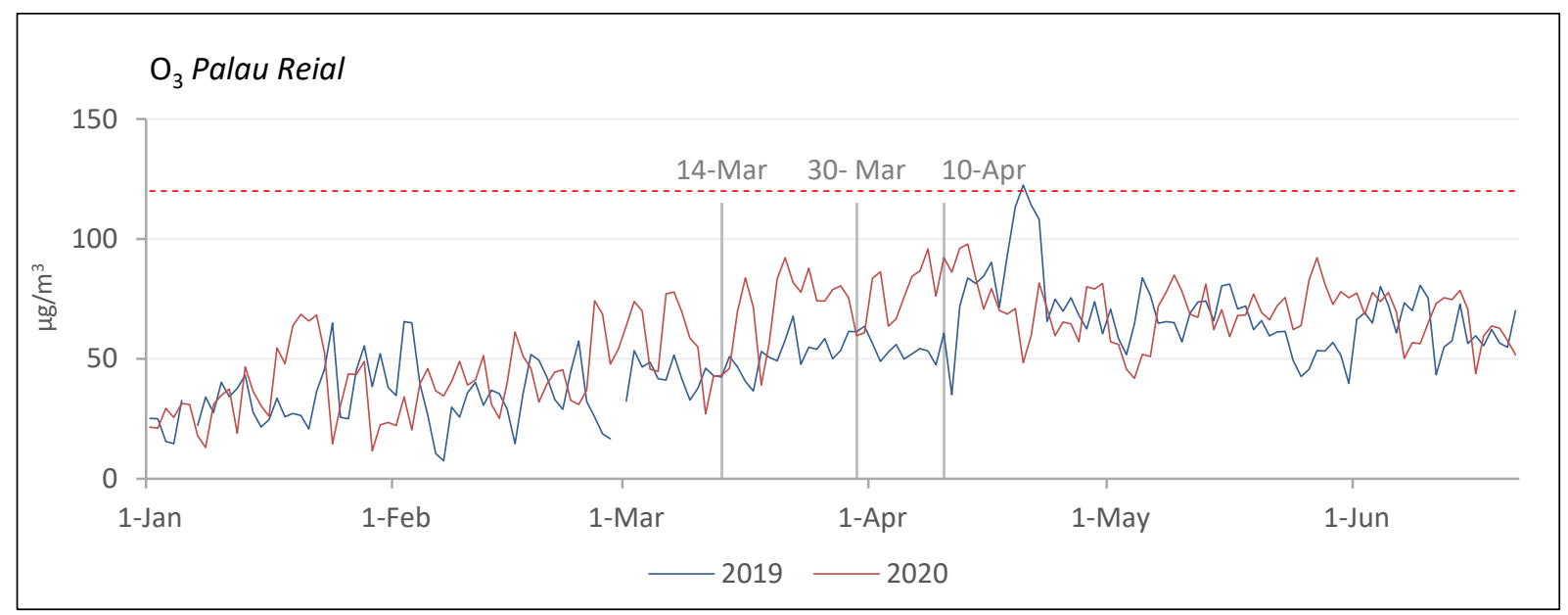

Source: authors' own elaboration based on data from the XVPCA

In summary, the reductions of immissions in Barcelona from March until June 2020, compared to those of 2019, are statistically significant, apart from the case of ozone. Figure 9 shows the weekly average values for the pollutant immissions analysed during the 2019-2020 study period. The colour code identifies the weeks with the lowest values in green tones, and those with the highest values in red. The immissions averages by pollutant and station are indicated in the centre of the graphic. The values of all pollutants are expressed in $\mu \mathrm{g} / \mathrm{m}^{3}$, except for $\mathrm{CO}$, which is in $\mathrm{mg} / \mathrm{m}^{3}$.

In Figure 9, we can see how the highest weekly average values were generally concentrated in January and February and that, from March onwards, they begin to move towards lower values. This pattern applies to both years and tallies with the generally accepted fact that pollutant concentrations, except ozone, reduce with the arrival of spring. This is a result of: 1) the decreased frequency of thermal inversions; 2) surface heating and the associated convection that diffuses pollutants, and 3) more dynamism in synoptic conditions and increased advection. Even so, in 2020, March to June recorded the lowest weekly averages, with a predominance of green colours in the figure below. 
Figure 9. Comparative table showing the distribution

of average weekly pollutant immissions in 2019 and 2020

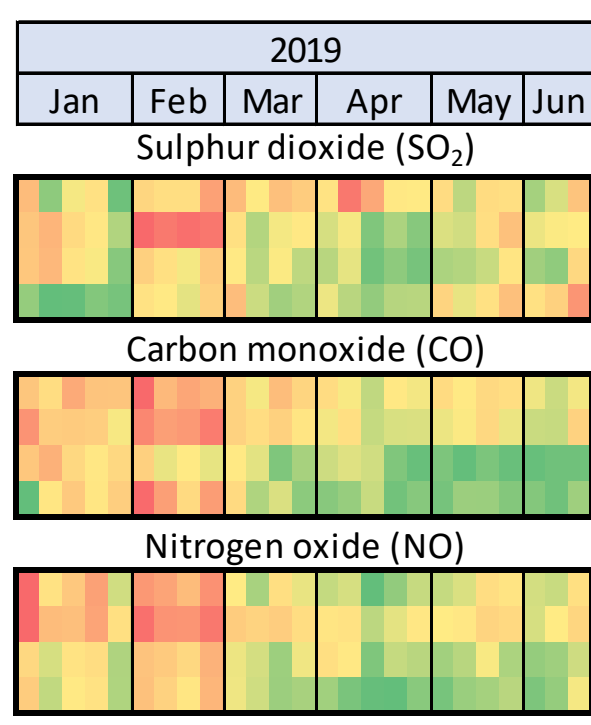

Nitrogen oxides (NOx)

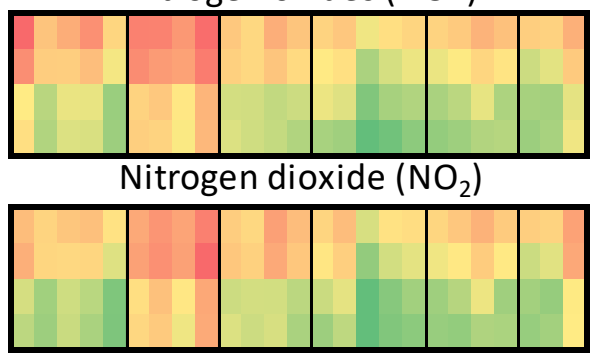

Particulate matter $\left(\mathrm{PM}_{10}\right)$

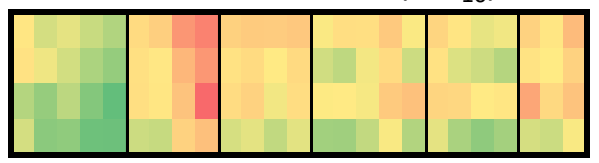

Ozone $\left(\mathrm{O}_{3}\right)$

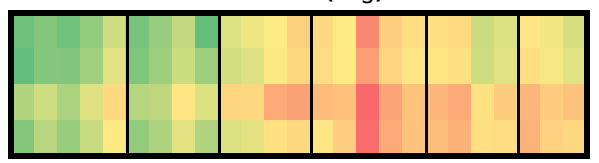

$\bar{X}$

\begin{tabular}{l|c|}
1,67 & Eixample \\
1,69 & Gràcia St Ger. \\
1,39 & Vall d'Hebron \\
1,43 & Palau Reial
\end{tabular}

\begin{tabular}{l|c|c}
0,42 & Eixample & 0,26 \\
0,42 & Gràcia St Ger. & 0,34 \\
0,31 & Vall d'Hebron & 0,31 \\
0,33 & Palau Reial & 0,26
\end{tabular}

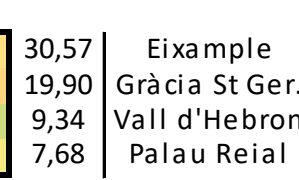

7,68 Palau Reial

\begin{tabular}{c|c|c}
97,62 & Eixample & 63,60 \\
76,85 & Gràcia St Ger. & 51,65 \\
45,61 & Vall d'Hebron & 34,21 \\
41,10 & Palau Reial & 28,78
\end{tabular}

Palau Reial 28,78

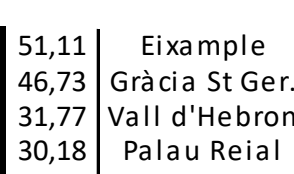

30,18 Palau Reial

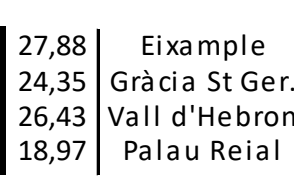

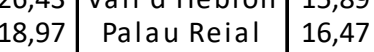

\begin{tabular}{l|c}
42,61 & Eixample \\
42,93 & Gràcia St Ger. \\
58,95 & Vall d'Hebron \\
51,85 & Palau Reial
\end{tabular}

Maximum values

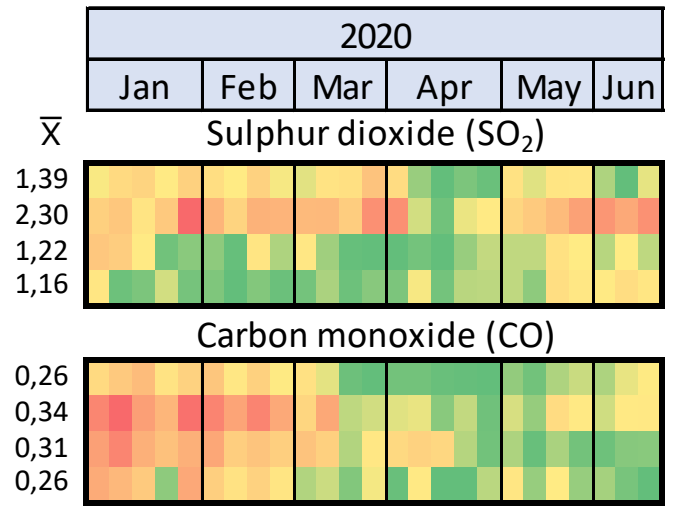

Nitrogen oxide (NO)

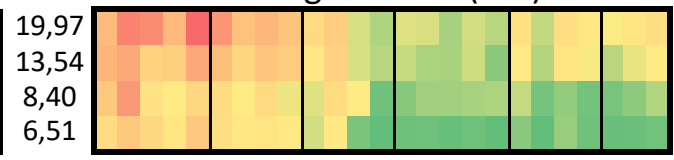

Nitrogen oxides (NOx)

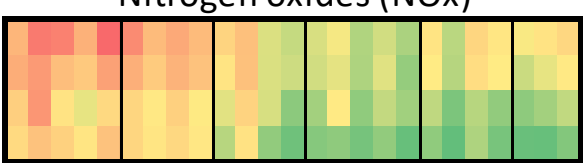

Nitrogen dioxide $\left(\mathrm{NO}_{2}\right)$

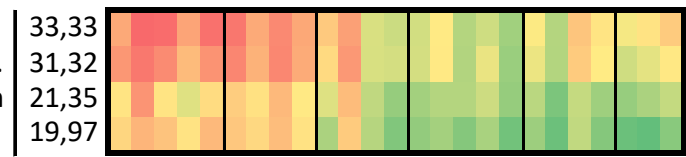

Particulate matter $\left(\mathrm{PM}_{10}\right)$

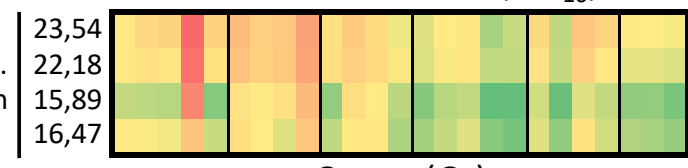

Ozone $\left(\mathrm{O}_{3}\right)$

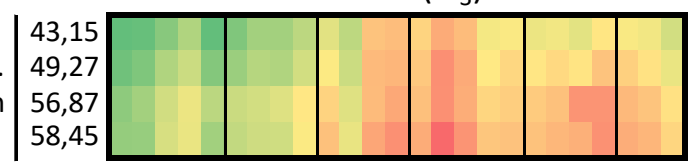

Minimum values

Source: authors' own elaboration based on data from the XVPCA

We can see that in the months prior to the first state of alert in 2020, the immissions were slightly below those of 2019 for all pollutants, except $\mathrm{PM}_{10}$ and $\mathrm{O}_{3}$. Then, during the first state of alert, this decrease is accentuated and becomes much more visible and evident; a general decline with significant percentage reductions. Thus, depending on the pollutant and season, we observed reductions of up to $80.3 \%$ during the early stages of the state of alert, with typical decreases ranging between 30 and $60 \%$. These decreases in immissions were produced by the drop in economic activity, particularly industrial activity, and the sharp decrease in mobility that led to considerably reduced road traffic. In this context, the significant level to which economic activity 
and traffic are responsible for generating polluting immissions is reflected by the fact that in the 2019 period analysed, the absolute minimums for all immissions, except $\mathrm{PM}_{10}$ and $\mathrm{O}_{3}$, were recorded during the Easter week ( $3^{\text {rd }}$ week of April: day 15 to 21$)$.

On a monthly basis, in April 2021 the maximum reduction was reached compared to 2019 in all pollutants, except $\mathrm{CO}$ and $\mathrm{O}_{3}$. The case of $\mathrm{NO}_{x}$ is paradigmatic of the evolution of reductions throughout the first six months of 2021: January, +4.19\%; February, -26.26\%; March, -48.98 \%; April, $-62.98 \%$; May, $-54.14 \%$, and June, $-46.10 \%$.

Nevertheless, we should also point out that the reduction of immissions during the first part of the first state of alert (March and April) was partly due to favourable meteorological conditions for pollutant dispersion, given that both months experienced considerable rainfall, especially April, and were quite windy.

In terms of ozone and its differentiated behaviour compared to the decreases seen in the other pollutant immissions, it should be noted that ozone is a secondary pollutant which, rather than being emitted directly into the atmosphere, is formed within it by photochemical reactions involving light and other pollutants. This means that the cleaner air would actually increase solar radiation, making the conditions more favourable for ozone genesis. However, April 2020 was characterised by abundant cloudiness, so the explanation is probably to be found in other chemical processes (Tobías et al., 2020).

\section{The reduction of $\mathrm{CO}_{2}$ and other greenhouse gas emissions in 2020 and their continuity}

The air pollution analysis made for Barcelona is a public health concern at a local scale. At first nothing to do with a global effect. Nevertheless, it is perfectly plausible to assume that greenhouse gas emissions would have drastically reduced during the almost global lockdown, just like the gases that pollute the air in our cities, and that this should have a positive effect on the annual emissions balance for 2020. The stoppage or closure of many industries and the sharp decline in road transport, commercial aviation and certain types of maritime transport (cruises, for example), as well as economic activities like construction, tourism, the holding of conferences, etc., reduced fossil fuel consumption and, therefore, $\mathrm{CO}_{2}$ emissions. Several studies with a substantial and urgent interest in such a remarkable and significant matter for our planet's system confirmed this. 
A review of some of these studies shows that the maximum reduction occurred in mid-April when $\mathrm{CO}_{2}$ emissions were more than $25 \%$ lower than normal, and other polluting gases such as $\mathrm{NO}_{x}$ were approximately 35 \% below their typical values (Forster et al., 2020) (Figure 10). The key result is an abrupt $8.8 \%$ decrease in global $\mathrm{CO}_{2}$ emissions (-1551 $\left.\mathrm{Mt} \mathrm{CO} 2\right)$ in the first half of 2020 compared to the same period in 2019 (Liu et al., 2020). The other main greenhouse gases, nitrous oxide $\left(\mathrm{N}_{2} \mathrm{O}\right)$ and methane $\left(\mathrm{CH}_{4}\right)$ originate from sources that were less sensitive to the economic shutdown and therefore showed more moderate decreases, reaching just over $5 \%$ at the most critical point. After hitting their minimums, the emissions began to increase in line with the return of socio-economic activity.

The second wave of the pandemic, despite being as serious as the first with a high number of infections, especially in Europe, was quite different. The arrival of autumn in the northern hemisphere brought new restrictions on travel and economic activity, making any precise forecasting of emission values for 2020 as a whole entirely hypothetical. Any estimates are hinged on the unknown evolution of the virus, its effect on normal patterns of behaviour at Christmas (which traditionally involves intense economic activity) and on the diverse range of more or less restrictive measures introduced to control the spread of infection in different countries and regions. Even so, the general upward trend of the annual $\mathrm{CO}_{2}$ emissions curve will undoubtedly show a dip in 2020. The reduction may be around $7 \%$ (Le Quéré et al., 2020), which would only represent a few tenths of parts per million in $\mathrm{CO}_{2}$ "savings" and have no effect on global warming. A recent analysis of Nature.News, based in the data of the Carbon Monitor programme, concludes that, after rising steadily for decades, global $\mathrm{CO}_{2}$ emissions fell by $6.4 \%$, or 2.3 billion tonnes, in 2020, due to the COVID-19 (Tollefson, 2021).

In a report on the world energy outlook last October, the International Energy Agency indicated that its "updated assessment of the immediate effects of the pandemic on the energy system shows expected falls in 2020 of $5 \%$ in global energy demand, $7 \%$ in energy-related $\mathrm{CO}_{2}$ emissions and $18 \%$ in energy investment. Oil consumption is anticipated to decline by $8 \%$ in 2020 and coal use by $7 \%$. Renewables, especially those in the power sector, are less affected than other fuels by the pandemic and its aftermath". ${ }^{2}$ This estimated reduction in $\mathrm{CO}_{2}$ emissions is similar to that put forward by Le Quéré et al. (2020), and both point to an undoubtedly prominent dip in the emissions curve, which was also seen, albeit less obviously, in 2009 as a

2 Available at https://www.iea.org/reports/world-energy-outlook-2020/overview-and-key-findings\#abstract 
result of the financial crisis that took hold during the transition between the first and second decade of the twenty-first century ${ }^{3}$.

Figure 10. a) Percentage change in global average $\mathrm{CO}_{2}$ emissions from fossil fuels and other anthropogenic emissions for each day in 2020 (the dashed vertical lines mark the first day of the months from February to June). b) Percentage reductions in global average emissions in April 2020, compared with data from 2019 for $\mathrm{CO}_{2}$ and 2015 for the remaining pollutants, in the primary emitting countries, including international aviation

a

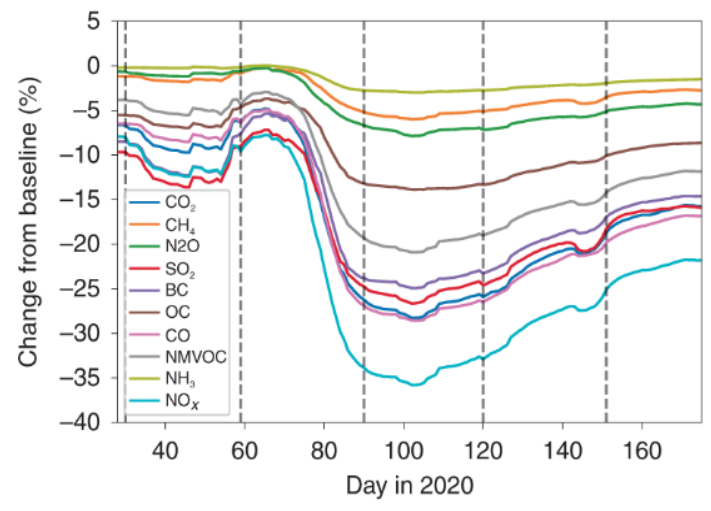

b

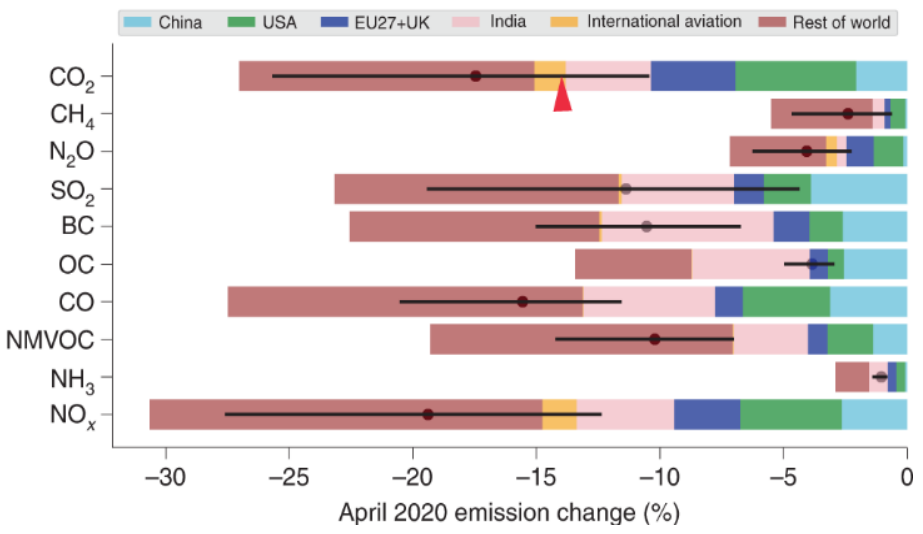

Source: Forster et al. (2020)

Given the appearance of a second wave of the pandemic in the boreal autumn, if 2020 saw an approximate $8 \%$ reduction in global $\mathrm{CO}_{2}$ emissions compared to 2019 , the dip in the evolution of these emissions should be evident (Figure 11). It should be noted that according to data from the International Energy Agency, countries with "advanced economies" have been steadily declining, albeit very slightly, since 2010. Since the economic crisis at the turn of the decade, which caused a dip in emissions in 2009 only to see them swiftly recover the following year, the reduced use of fossil fuels for power generation and in other sectors, in parallel with the increased use of renewables, have contributed to a steady decline in emissions. In the rest of the world, the evolution of $\mathrm{CO} 2$ emissions has been quite different. They continued to increase until reaching maximums in 2019. Since then, the increases have begun to slow. The differing evolution of emissions in the two groups of countries has inverted their percentage shares of the global total: in 2000, advanced economies were responsible for $12.6 \mathrm{Gt}$, and the rest of the world emitted $10.5 \mathrm{Gt}$, while in 2019, the rest of the world emitted $22.0 \mathrm{Gt}$, which was 
practically twice as much as the advanced economies, who were responsible for $11.3 \mathrm{Gt}$ (Figure 11).

Figure 11. Annual $\mathrm{CO}_{2}$ emissions of advanced economies (blue) and the rest of the world (red), for the period 2000-2019 plus their predicted emissions for 2020, and their trends (black)

COVID-19

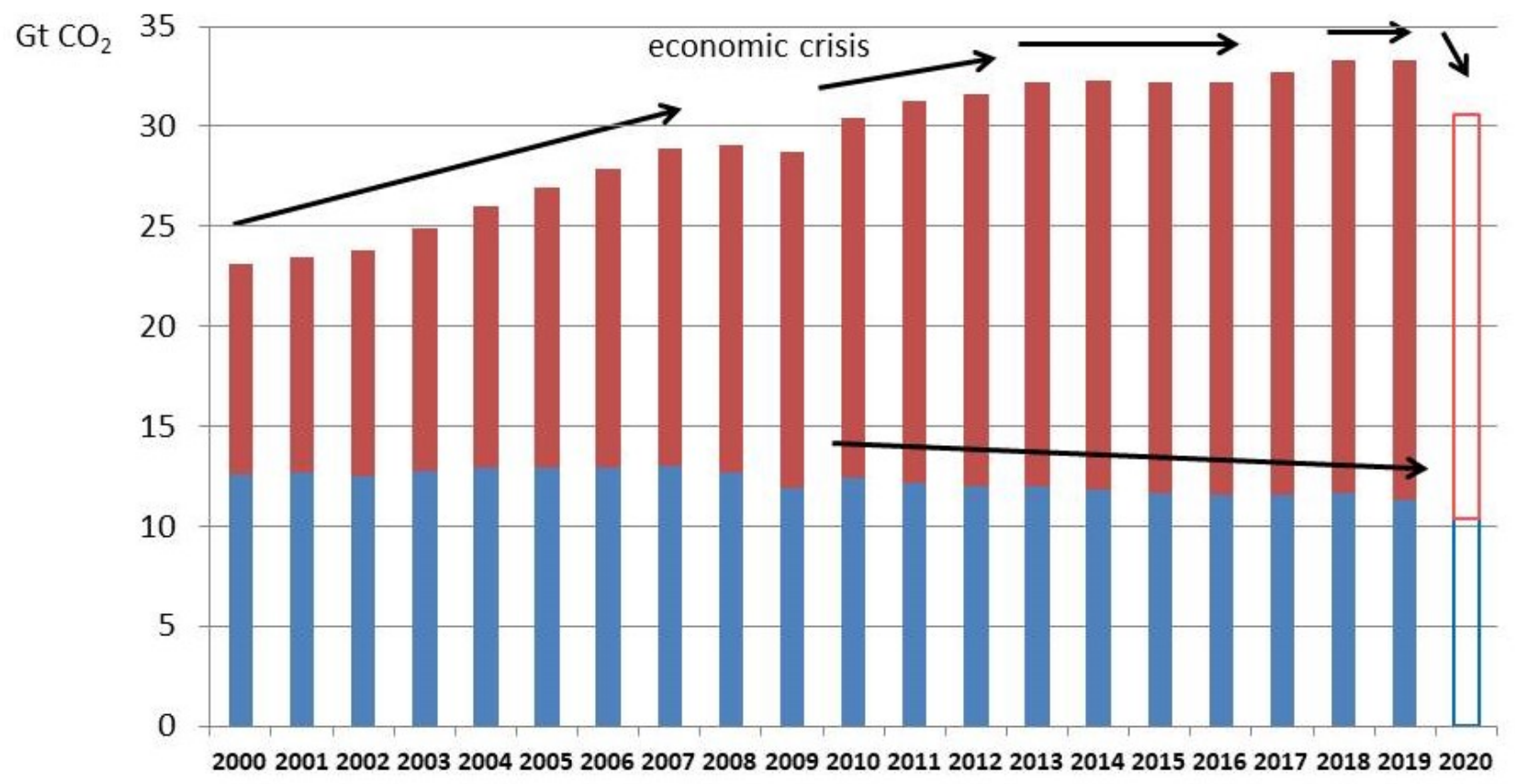

Source: authors' own elaboration based on data from the IEA (https://www.iea.org/articles/global-co2-emissions-in-2019)

We must bear in mind that the decrease in $\mathrm{CO}_{2}$ emissions between 2019 and 2020 does not imply a decrease in the $\mathrm{CO}_{2}$ concentration in the atmosphere, which continues to increase unabated (Walsh et al., 2017). Naturally, the increase in its atmospheric concentration will be less pronounced than in previous years, but it will not be sufficient to change its upward trend overall.

\section{Discussion and conclusions}

During the first state of alert in Spain (March and April of 2020) declared by the COVID-19 pandemic, there was a general statistically significant decrease in immissions of atmospheric pollutants in the city of Barcelona, with the exception of ozone. Depending on the pollutant and control station, reductions of up to $80.3 \%$ were observed during the early stages of the state of alert, with typical declines ranging from 30-60\%. These decreases in immissions were produced 
by the fall in economic activity, including industrial activity, and the sharp decrease in the density of road traffic.

It should also be noted that the reduction in immissions during the first part of the first state of alert was due in part to the favourable meteorological conditions for the dispertion of pollutants, since that March and especially April experienced considerable rainfall and were quite windy, compared to the same months of 2019.

The photochemical genesis of the ozone explains the opposite behaviour respect to the other pollutant immissions. The cleaner air would actually increase solar radiation, making the conditions more favourable for ozone genesis.

The influence of traffic on the decline in immissions was clear in the case of nitrogen oxides, although the reductions in immsissions were greater than the cutting of traffic density. So other causes, such as the decline in economical (industrial) activity, were also relevant.

The reality of global warming, which is the most evident manifestation of current climate change, is not up for discussion in science. The vast amount of meteorological data recorded by surface weather stations, as well as other data from satellites and natural indicators, tells us the planet is warmer than it was 40 years ago. Furthermore, the warming is global, it affects every part of the globe and all its regions. And it is also uneven, with the Arctic basin having suffered the most damage so far (IPCC, 2013). The Mediterranean basin, to which much of Spain belongs climatically, is also considered a hot-spot (Martin-Vide, 2020), with temperature increases higher than the planetary average (Cramer et al., 2018). The evidence is so overwhelming, that even in denialist circles, which are increasingly diminished but still aggressive under the shroud of anonymity offered by social networks, people are beginning to accept that the planet's temperature has increased. What they do not accept, however, is that the cause of this increased temperature is anthropic. Climate change denial uses the Earth's natural variability to explain the current warming or makes false scientific, economic, political and humanitarian arguments (Maslin, 2019). The Working Group I of the Assessment Report 6" has closed this debate: "It is indisputable that human activities are causing climate change, making extreme climate events, including heat waves, heavy rainfall, and droughts, more frequent and severe" (IPCC, 2021).

In the northern hemisphere's spring, large swathes of humanity were confined to their homes due to the COVID-19 pandemic (the disease), which was produced by SARS-CoV-2 (the virus). With the exception of healthcare and the necessary government offices, all other industries, transport and services were forced to grind to a halt, with many countries only permitting essential activities 
to provide and distribute food and medicine and maintain essential services and infrastructures. This resulted in an immediate drop in air pollution levels in urban and industrial areas and around major roads. The effect was particularly notable in cities, where the improvements in air quality were staggering. From the reduction in $\mathrm{P}_{2.5}$ particles in the Chinese megalopolises (He et al., 2020), to the $\mathrm{NO}_{2}$ levels in Madrid and Barcelona (Baldasano, 2020), $\mathrm{NO}_{2}$ plus $\mathrm{CO}$ and $\mathrm{PM}_{10}$ in Rio de Janeiro (Dantas, 2020), and $\mathrm{SO}_{2}, \mathrm{NO}_{2}, \mathrm{CO}, \mathrm{O}_{3}, \mathrm{PM}_{10}, \mathrm{PM}_{5}$ and $\mathrm{NH}_{3}$, in New Delhi (Mahato et al., 2020), etc. The analyses of Barcelona outlined in the previous sections of this article also confirm a decrease in air pollution during the state of alert and corroborate, albeit with certain nuances, the patterns seen elsewhere in the world. The unprecedented images of wild animals wandering through city streets, together with the pollutant-free air, seemed to integrate nature into the most artificial and anthropized environment (Rutz et al., 2020). As a paradox to the health catastrophe, to the pneumonia that was seriously and often fatally compromising the lung function of the patients in hospital ICUs, those who stayed well were able to open their windows and take deep breaths of an air free from harmful particles and gases.

The coronavirus pandemic has taught us that the world is fragile, subject to chaos theories (Smith, 2001), where small differences in the initial situation can produce wildly varying results; and to catastrophe theory (Thom, 1977; Martín Vide, 1993), through which a presumably minimal event can suddenly unleash effects of an unimaginable magnitude. It has clearly shown us that humanity operates within tight limits and that there are no borders; that, despite it being almost impossible to isolate oneself on a hyper-connected planet, isolation and confinement have proved the most effective strategies to reduce the incidence of the disease. The pandemic has shown us that solidarity is our best weapon in the face of such adversity, on all levels, from the planetary and supranational to local neighbourhoods. We live together -we cohabitate- on the same planet, which is not the same as coexisting. We also share the planet with other living beings, many of them under the threat of extinction. In fact, today, we are losing animal and plant life at such a rate it is widely accepted we are living through (and have been for decades, probably during the last few centuries) the Sixth Extinction (Kolbert, 2015). Furthermore, it is estimated that some $86 \%$ of the terrestrial species that share our planet have yet to be described (Mora et al., 2011). Since the end of the eighteenth century, the reproductive success of the human species has been to the detriment of many other living species that have either disappeared entirely or seen their numbers decline to a threshold that seriously jeopardises their continuity on the planet.

We will overcome the coronavirus, and the pandemic will come to an end. Nevertheless, let us not forget that in its place will come a pandemic of even greater proportions; one that has been 
active for decades, with no foreseeable end; one that may appear less harmful than coronavirus (but which we must face without a protective mask), and one that is negated by climate change denial with its dubious objectives and conspiratorial visions beyond all reason (which also seem to fuel the denial of coronavirus). Science, with its scientific method, or, in other words, its process of systematic observation, rigorous measurement, hypothesis formulation, repeated experimentation (as many times as is necessary), extraction of results and consequential acceptance or rejection of the initial hypotheses, has long since "certified" the reality of global warming and established its anthropic origin with a degree of confidence that is already conclusive.

When the pandemic finally subsides and allows for economic recovery, we must ensure $\mathrm{CO}_{2}$ emissions do not return to pre-pandemic levels. If no action is taken, the benefit of reducing greenhouse gas emissions during the COVID-19 pandemic will have been temporary and minimal (Lambert, 2020). In other words, we must try, by all and any means, to ensure governments, companies, workers and all economic and social agents recognise the current situation as a phenomenal opportunity to embrace a just and sustainable economic, social and environmental recovery plan. We must integrate, in a balanced way, the travel-saving advantages of telecommuting; swap everyday consumer habits for more moderate and environmentally friendly ones; reinforce public services, including the health service, which has already been mistreated, and optimise and invest the resources earmarked for recovery in clean production methods and stimuli to decisively promote the inevitable energy transition and definitively renounce fossil fuels. The formula for success lies in changing the economic and energy model; the well-trodden paths of capitalism no longer serve us (Park, 2015). We cannot return to the old normal that we longed for in the most challenging moments of the pandemic. Instead, we must look to a new normal, one where the planet, its countries, its cities and peoples are committed to real progress, solidarity and sustainability.

The December 2015 Paris Agreement (United Nations, 2015) concluded that, as the principal cause of global warming, fossil fuels were no longer a viable energy source. Climate change science warns us that increasing the Earth's temperature by $2{ }^{\circ} \mathrm{C}$ compared to the pre-industrial period, or, more specifically, the last decades of the nineteenth century, will have severe repercussions for humanity, some of which will be irreversible. And that, if at all possible, we must limit the increase to $1.5{ }^{\circ} \mathrm{C}$. With the global average surface air temperature already exceeding one net degree centigrade $\left(1.1^{\circ} \mathrm{C}\right)$ (IPCC, 2018; IPCC, 2021), we are already approaching this threshold. We are running out of time to prevent the worst from happening. 
Paradoxically, the coronavirus tragedy may have given us a chance to stop the climate change pandemic. However, we will only succeed if we can gather every last drop of political will, draw on full citizen commitment, solidarity between peoples, scientific knowledge and help from technology. To return to the old normal of just over one year and a half ago, is to condemn the planet to exceed the $1.5{ }^{\circ} \mathrm{C}$ thermal increase threshold, and, in all likelihood, the $2{ }^{\circ} \mathrm{C}$ limit as well. The world would need to cut carbon emissions by $7.6 \%$ per year for the next decade to prevent the globe from warming more than $1.5{ }^{\circ} \mathrm{C}$ above pre-industrial levels, according to the United Nations Environment Programme. So that reductions would be even larger than 2020's drop in emissions (Tollefson, 2021). If we can rise to the challenge outlined above by taking a comprehensive approach to the reduction of emissions, and not only greenhouse gases but all air pollutants, we would also benefit from an almost immediate improvement in the air quality in our cities, which, every year, takes the lives of too many people ahead of their time. The World Health Organization estimates that "around 7 million people die every year from exposure to fine particles in polluted air that penetrate deep into the lungs and cardiovascular system, causing diseases including stroke, heart disease, lung cancer, chronic obstructive pulmonary diseases and respiratory infections, including pneumonia" (WHO, 2018).

If air pollution and greenhouse gas emissions are tackled together, it is imperative to drastically reduce both. Although their specific origins and immediate effects are different, in the end both processes produce environmental damage and negative impacts on human health. This joint vision of both problems, brought to light by COVID-19, is a comprehensive way of addressing anthropic impacts on the atmospheric environment and limiting the global warming. This has been the driving idea of this article.

A paradoxical aspect is the effect of aerosols or fine particles, such as PM10. They reflect solar radiation, making the Earth's surface below them slightly cooler than it would be otherwise. Most of the particles have a negative forcing, that is, they cool the surface of the planet, as occurs after large volcanic eruptions.

As a corollary, COVID-19 has reminded us of the permeability between processes at different scales on the planet. This should encourage us, more than ever, because we live on an interconnected planet, to use comprehensive approaches, or at least, not to lose sight of what is happening in broader or more detailed spatial contexts. Our studies, and the scale of our analyses, must be conducted in as much detail as possible and consider the conceptual, factual, 
temporal and territorial frameworks in which they are embedded. Should that not be the very purpose of Geography in the twenty-first century?

Acknowledgements: To the CLICES CGL2017-83866-C3-2-R project and the 2017 SGR 1362 Climatology Group. The project was also carried out within the framework of the interests of The Water Research Institute at the University of Barcelona (IdRA, UB) and the Royal Academy of Sciences and Arts of Barcelona (RACAB).

Authorship statement: The authors declare no conflict of interest. The participation of the authors in the article is as follows. Javier Martín-Vide: Coordination, writing, results and conclusions. Alberto Zayas: Methodology, statistical analysis, writing and results. Ferran Salvador: Idea and copy editing. M ${ }^{a}$ Carmen Moreno-García: Literature review and proofreading. 


\section{References}

AEMET (n.d.). Monthly climatological

summaries. http://www.aemet.es/en/serviciosclimaticos/vigilancia_clima/resumenes?w=1\&k= $\underline{\text { cat }}$

Baldasano, J.M. (2020). COVID-19 lockdown effects on air quality by NO2 in the cities of Barcelona and Madrid (Spain). Science of The Total Environment, 741, 140353. https://doi.org/10.1016/j.scitotenv.2020.140353

Costello, A., Abbas, M., Allen, A., Ball, S., Bell, S., Bellamy, R., Friel, S., Groce, N., Johnson, A., Kett, M., Lee, M., Levy, C., Maslin, M., McCoy, D., McGuire, B., Montgomery, H., Napier, D., Pagel, C., Patel, J., de Oliveira, J.A., Redclift, N., Rees, H., Rogger, D., Scott, J., Stephenson, J., Twigg, J., Wolff, J., \& Patterson, C. (2009). Managing the health effects of climate change. The Lancet, 373(9676), 1693-1733. https://doi.org/10.1016/s0140$\underline{6736(09) 60935-1}$

Cramer, W., Guiot, J., Fader, M., Garrabou, J., Gattuso, J.P., Iglesias, A., Lange, M., Lionello, P., Llasat, M.C., Shlomit, P., et al. (2018). Climate change and interconnected risks to sustainable development in the Mediterranean. Nature Climate Change, 8(11), 972 980. hitps://hal.archives-ouvertes.fr/hal-01911390/document

Dantas, G., Siciliano, B., Boscaro França, B., Da Silva, C.M., \& Arbilla, G. (2020). The impact of COVID-19 partial lockdown on the air quality of the city of Rio de Janeiro, Brazil. Science of The Total Environment, 729, 139085. https://doi.org/10.1016/j.scitotenv.2020.139085

Forster, P.M., Forster, H.I., Evans, M.J., Gidden, M.J., Jones, C.D., Keller, C.A., Lamboll, R.D., Le Quéré, C., Rogelj, J., Rosen, D., Schleussner, C-F., Richardson, T.B., Smith, C.J., \& Turnock, S.T. (2020). Current and future global climate impacts resulting from COVID-19. Nature Climate Change, 10, 913-919. https://doi.org/10.1038/s41558-020-0883-0

He, G., Pan, Y., \& Tanaka, T. (2020). The short-term impacts of COVID-19 lockdown on urban air pollution in China. Nature Sustainability, 3, 1005-10011. https://doi.org/10.1038/s41893$\underline{020-0581-y}$

IPCC (2013). Climate Change 2013: The Physical Science Basis. Contribution of Working Group I to the Fifth Assessment Report of the Intergovernmental Panel on Climate Change. Cambridge University Press. https://www.ipcc.ch/report/ar5/wg1/ 
IPCC (2018). Global Warming of $1.5{ }^{\circ} \mathrm{C}$. Special Report. Summary for Policymakers. World Meteorological Organization. https://www.ipcc.ch/sr15/

IPCC (2021, In Press). Climate Change 2021: The Physical Science Basis. Contribution of Working Group I to the Sixth Assessment Report of the Intergovernmental Panel on Climate Change. [Masson-Delmotte, V., Zhai, P., Pirani, A., Connors, S.L., Péan, C., Berger, S., Caud, N., Chen, Y., Goldfarb, L., Gomis, M.I., Huang, M., Leitzell, K., Lonnoy, E., Matthews, J.B.R., Maycock, T.K., Waterfield, T., Yelekçi, O., Yu, R., \& Zhou, B (Eds.)]. Cambridge University Press.

Lambert, J. (2020, August 7). Emissions dropped during the COVID-19 pandemic. The climate impact won't last. Science News. https://www.sciencenews.org/article/covid-19-coronavirusgreenhouse-gas-emissions-climate-change

Le Quéré, C., Jackson, R.B., Jones, M.W., Smith, A.J.P., Abernethy, S., Andrew, R.M., De-Gol, A.J., Willis, D.R., Shan, Y., Canadell, J.G., Friedlingstein, P., Creutzig, F., \& Peters, G.P. (2020). Temporary reduction in daily global $\mathrm{CO}_{2}$ emissions during the COVID-19 forced confinement. Nature Climate Change, 10, 647-653. https://doi.org/10.1038/s41558-020$\underline{0797-x}$

Liu, Z., Ciais, P., Deng, Z., Lei, R., Davis, S.J., Feng, S., Zheng, B., Cui, D., Dou, X., Zhu, B., Guo, R., Ke, P., Sun, T., Lu, C., He, P., Wang, Y., Yue, X., Wang, X., Lei, Y., Zhou, H., ... Schellnhuber, H.J. (2020). Near-real-time monitoring of global $\mathrm{CO}_{2}$ emissions reveals the effects of the COVID-19 pandemic. Nature Communications, 11, 5172. https://doi.org/10.1038/s41467-020-18922-7

Mahato, S., Pal, S., \& Ghosh, K.G. (2020). Short-term exposure to ambient air quality of the most polluted Indian cities due to lockdown amid SARS-CoV-2. Environmental Research, 188, 109835. https://doi.org/10.1016/j.envres.2020.109835

Martín Vide, J. (1993). La teoría de catástrofes y la geografía: Aplicaciones en climatología (The theory of catastrophes and geography: Applications in climatology). Revista de Geografía, 27, $21-32$

Martín Vide, J. (2012). Reflexionando sobre la Geografía [Reflecting on Geography]. In V. Gozálvez Pérez \& J.A. Marco Molina (Eds.), Geografía: retos ambientales y territoriales [Geography: environmental and territorial challenges] (pp.11-14). XXII Congress of the Spanish Association of Geographers, University of Alicante. Spanish Association of Geographers. 
Martín Vide, J. (2020). Cambio climático en España. Realidades [Climate change in Spain. Realities]. In J. Romero González \& J. Olcina Cantos (Eds.), Cambio climático en el Mediterráneo. Procesos, riesgos y políticas [Climate change in the Mediterranean. Processes, risks and policies] (pp.75-86). Tirant lo Blanch.

Maslin, M. (2019, November 28). The five corrupt pillars of climate change denial. The Conversation. $\quad$ https://theconversation.com/the-five-corrupt-pillars-of-climate-change-denial$\underline{122893}$

METEOCAT (n.d.). Monthly bulletins. https://www.meteo.cat/wpweb/climatologia/el-climaara/butlleti-mensual/

Mora, C., Tittensor, D.P., Adl, S., Simpson, A.G.B., \& Worm, B. (2011). How Many Species Are There on Earth and in the Ocean? PLOS Biology, 9(8), e1001127. https://doi.org/10.1371/journal.pbio. 1001127

Park, J.T. (2015). Climate Change and Capitalism. Consilience, 14, 189-

206. https://www.jstor.org/stable/26188749

Kolbert, E. (2014). The Sixth Extinction: An Unnatural History. Henry Holt and Co.

Rockström, J., Steffen, W., Noone, K., Persson, Å., Chapin, F.S., III, Lambin, E., Lenton, T.M., Scheffer, M., Folke, C., Schellnhuber, H.J., Nykvist, B., De Wit, C.A., Hughes, T., van der Leeuw, S., Rodhe, H., Sörlin, S., Snyder, P.K., Costanza, R., Svedin, U., Falkenmark, M., Karlberg, L., Corell, R.W., Fabry, V.J., Hansen, J., Walker, B., Liverman, D., Richardson, K., Crutzen, P., \& Foley, J. (2009). Planetary boundaries: exploring the safe operating space for humanity. Ecology and Society, 14(2),

32. http://www.ecologyandsociety.org/vol14/iss2/art32/

Rutz, C., Loretto, M., Bates, A.E., Davidson, S.C., Duarte, C.M., Jetz, W., Johnson, M., Kato, A., Kays, R., Mueller, T., Primack, R.B., Ropert-Coudert, Y., Tucker, M.A., Wikelski, M., \& Cagnacci, F. (2020). COVID-19 lockdown allows researchers to quantify the effects of human activity on wildlife. Nature Ecology \& Evolution, 4, 1156-1159. https://doi.org/10.1038/s41559-020$\underline{1237-z}$

Smith, P. (2003). Chaos. A theoretical explanation. Cambridge University Press.

Tobías, A., Carnerero, C., Reche, C., Massagué, J., Via, M., Minguillón, M.C., Alastuey, A., \& Querol, X. (2020). Changes in air quality during the lockdown in Barcelona (Spain) one month 
into the SARS-CoV-2 epidemic. Science of the Total Environment, 726, 138540. https://doi.org/10.1016/j.scitotenv.2020.138540

Thom, R. (1977). Stabilité structurelle et morphogénèse: essai d'une théorie générale des modèles. InterÉditions.

Tollefson, J. (2021, January 15). COVID curbed carbon emissions in 2020 - but not by much. Nature News. https://www.nature.com/articles/d41586-021-00090-3

United Nations (2015). Paris

Agreement. https://unfccc.int/files/essential_background/convention/application/pdf/english _paris_agreement.pdf

Walsh, B., Ciais, P., Janssens, I. A., Peñuelas, J., Riahi, K., Rydzak, F., van Vuuren, D.P., \& Obersteiner, M. (2017). Pathways for balancing CO2 emissions and sinks. Nature communications, 8, 14856. https://doi.org/10.1038/ncomms 14856

World Health Organization-WHO-OMS (2018, May 2). 9 out of 10 people worldwide breathe polluted air, but more countries are taking action. https://www.who.int/news/item/02-05-20189-out-of-10-people-worldwide-breathe-polluted-air-but-more-countries-are-taking-action

World Health Organization (2021, August 24). Weekly epidemiological update on COVID-19-24 August 2021. https://www.who.int/publications/m/item/weekly-epidemiological-update-oncovid-19-24-august-2021 